\title{
Correction to: Ketogenic diet for mitochondrial disease: a systematic review on efficacy and safety
}

Heidi Zweers ${ }^{1,2^{*}+} \mathbb{D}$, Annemiek M. J. van Wegberg ${ }^{1,2+}$, Mirian C. H. Janssen ${ }^{2,4}$ and Saskia B. Wortmann ${ }^{2,3}$

\section{Correction to: Orphanet J Rare Dis (2021) 16:295 https://doi.org/10.1186/s13023-021-01927- \\ w}

Following the publication of the original article [1], the authors requested to move the declaration "SBW has the ERAPERMED2019-310 grant-Personalized Mitochondrial Medicine: Optimizing diagnostics and treatment for patients with mitochondrial diseases" from the "Competing interests' section to the 'Funding' section of the article.

The 'Funding' section now states: "SBW has the ERAPERMED2019-310 grant-Personalized Mitochondrial Medicine: Optimizing diagnostics and treatment for patients with mitochondrial diseases".

The 'Competing interests' section now states: "The authors declare that they have no competing interests".

The 'Funding' and 'Competing interests' sections have already been updated in the original article.

\section{Author details}

${ }^{1}$ Department of Gastroenterology and Hepatology - Dietetics, Radboudumc, Postbus 9101, 6500 HB Nijmegen, The Netherlands. ${ }^{2}$ Radboud Center for Mitochondrial Medicine (RCMM), Amalia Children's Hospital, Radboudumc, Nijmegen, The Netherlands. ${ }^{3}$ University Children's Hospital, Paracelsus Medical
University, Salzburg, Austria. ${ }^{4}$ Department of Internal Medicine, Radboudumc, Nijmegen, The Netherlands.

Published online: 27 September 2021

\section{Reference}

1. Zweers et al. Ketogenic diet for mitochondrial disease: a systematic review on efficacy and safety. Orphanet J Rare Dis. 2021;16:295. https:// doi.org/10.1186/s13023-021-01927-w.

\section{Publisher's Note}

Springer Nature remains neutral with regard to jurisdictional claims in published maps and institutional affiliations.

The original article can be found online at https://doi.org/10.1186/s13023021-01927-w.

*Correspondence: Heidi.Zweers-vanEssen@radboudumc.nl

${ }^{\dagger}$ Heidi Zweers and Annemiek M. J. van Wegberg have contributed equally to this work

${ }^{1}$ Department of Gastroenterology and Hepatology - Dietetics, Radboudumc, Postbus 9101, 6500 HB Nijmegen, The Netherlands

Full list of author information is available at the end of the article

(c) The Author(s) 2021. Open Access This article is licensed under a Creative Commons Attribution 4.0 International License, which permits use, sharing, adaptation, distribution and reproduction in any medium or format, as long as you give appropriate credit to the original author(s) and the source, provide a link to the Creative Commons licence, and indicate if changes were made. The images or other third party material in this article are included in the article's Creative Commons licence, unless indicated otherwise in a credit line to the material. If material is not included in the article's Creative Commons licence and your intended use is not permitted by statutory regulation or exceeds the permitted use, you will need to obtain permission directly from the copyright holder. To view a copy of this licence, visit http://creativecommons.org/licenses/by/4.0/. The Creative Commons Public Domain Dedication waiver (http://creativeco mmons.org/publicdomain/zero/1.0/) applies to the data made available in this article, unless otherwise stated in a credit line to the data. 